\title{
Industrial Policy as the Application of State Defense in the Era of Industrial Revolution 4.0
}

\section{Afrimadona, Shanti Darmastuti, Wiwiek Rukmi Dwi Astuti}

\begin{tabular}{|c|c|}
\hline \multirow{2}{*}{\multicolumn{2}{|c|}{ Afrimadona }} \\
\hline & \\
\hline Affiliation & $\begin{array}{l}\text { Universitas Pembangunan } \\
\text { Nasional Veteran }\end{array}$ \\
\hline City & Jakarta \\
\hline Country & Indonesia \\
\hline \multirow{2}{*}{\multicolumn{2}{|c|}{ Email : }} \\
\hline & \\
\hline \multicolumn{2}{|c|}{ Shanti Darmastuti } \\
\hline Affiliation & $\begin{array}{l}\text { Universitas Pembangunan } \\
\text { Nasional Veteran }\end{array}$ \\
\hline City & Jakarta \\
\hline Country & Indonesia \\
\hline \multicolumn{2}{|c|}{ Email $\quad:$} \\
\hline \multirow{2}{*}{\multicolumn{2}{|c|}{$\begin{array}{l}\text { shanti.darmastuti@upnvj.ac.id } \\
\text { Wiwiek Rukmi Dwi Astuti }\end{array}$}} \\
\hline & \\
\hline \multicolumn{2}{|c|}{ (Correspondence Author) } \\
\hline Affiliation & $\begin{array}{l}\text { Universitas Pembangunan } \\
\text { Nasional Veteran }\end{array}$ \\
\hline City & Jakarta \\
\hline Country & Indonesia \\
\hline \multirow{2}{*}{\multicolumn{2}{|c|}{$\begin{array}{l}\text { Email } \quad \vdots \\
\text { wiwiek.rukmi@upnvj.ac.id }\end{array}$}} \\
\hline & \\
\hline \multicolumn{2}{|l|}{ History } \\
\hline Submission & 7 September 2020 \\
\hline Review & 15 November 2020 \\
\hline \multicolumn{2}{|l|}{ Completed } \\
\hline Accepted & 10 December 2020 \\
\hline Available & 20 December \\
\hline Online & 2020 \\
\hline
\end{tabular}

DOI

10.51413/jisea.Vol1.Iss2.2020.92-109

Copyright

This is an open access article distributed under the term of the creative commons attribution 4.0 international licence

\begin{abstract}
The rapid change in the information technology in the age of Industry 4.0 requires the government to produce an innovative and competitive industrial policy in order to push for an independent economic development. Amids the trend of industry 4.0, states are faced with a challenge of advancing national industries, such as the energy, food and beverage, automotive, electronics, chemical, textile and textile products industries. Using literature review over a number of cases of industrial policies in East Asia, this article argues that a national interest-based industrial policy can be seen as an implementation of the so-called state defense. This is because industrial policy is the product of the thoughts of individual policy-makers who are also the citizens to whom the obligation of state defense applies. Thus, rather than simply asking the general individual citizens to do state defense, the state, represented by the individual policy-makers should also think of their policy in terms of state defense, that is the defense of public interest.
\end{abstract}

Key Words: industrial policy, industry 4.0, state defense, national interest

\section{Cite this article :}

Afrimadona, Darmastuti, S., \& Astuti, W. R. D. (2020). Industrial Policy as the Application of State Defense in the Era of Industrial Revolution 4.0. Journal of International Studies on Energy Affairs, 1(2), 92-109.

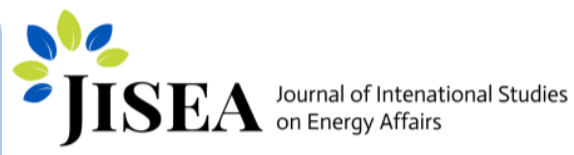




\section{INTRODUCTION}

State defense is a concept of defense and security that is state-centric and oriented to traditional threats. Although the definition of state defense has undergone a change from the definition contained in the legislative products of the cold war period, the definition and conception of state defense in general still implies an understanding of security in a traditional sense, namely armed threat. Although in many cases traditional security issues such as armed threats from outside are still relevant to the current world which is overshadowed by the emergence of a trend of power politics, especially in the East Asia region, non-traditional threats are no less important. In understanding state defense, it is necessary to examine the perceptions of factual and potential threats. Defending the state in the national aspect is closely related to non-traditional threat aspects such as the economic, social and cultural fields. Particularly in the economic sector, the economy is a means of domestic stability and is one of the means of determining the bargaining position of each country in relations between countries or international relations. Thus, national economic growth is the country's priority in the concept of state defense. Therefore, adjusting the definition of the conception of state defense with the changing times is a necessity.

Another problem with the concept of defending the state is that it is doctrinaire and implies that the responsibility to defend the state lies only with the citizens. It is not clear who is meant by citizens here, whether all individuals who live in the Unitary State of the Republic of Indonesia (NKRI) or citizens in the sense of the people (which is different from the government). If the concept of citizenship is defined in the first sense, then individual policy-makers who sit in government and who make political, economic and other decisions are also citizens. Therefore, the definitions and obligations attached to the conception of state defense also apply to them.

This problematic conception of state defense may invite criticism by seeing it as conceptual stretching. Our argument is that the 
problematization of state defense is not a conceptual stretching because the conception of state defense as stated in the 1945 Constitution is very multi-interpretative so that it opens up space for contestation of ideas and ideas in defining this concept. In this paper, we also try to provide a re-interpretation of the conception of state defense by broadening the subject (actor) not only to the individual Indonesian people but also to individual decision makers. If state defense is directed to safeguard the Republic of Indonesia and protect this country from various threats, then the reinterpretation of state defense that we offer should be acceptable. In this paper, we see that national interest-oriented economic policies are part of the government's state defense action. Thus, defending the country is also the responsibility of decision makers.

The Industrial Revolution 4.0 not only has the potential to overhaul the industrial conditions of a country, but also change various aspects of human life. Safeguarding domestic industries is one of the top priorities for the government. This security is mainly in the form of guaranteed energy availability for industries in the country. Thus, industrial policy within the conception of state defense becomes a relevant topic to be studied scientifically.

\section{METHOD}

Methodologically, this is a desk research. In this research, we review some other works related to industrial policy and reconceptualize this policy in order to fit in the realm of state defense we are discussing. In desk research, we collect available secondary data, both qualitative and quantitative, to construct our arguments. In analysing these data, we rely on thematic analysis, employing the axial coding scheme where any ideas representing each theme in our analysis are related to one another to compose a grand narrative of our arguments (Creswell, 2014).

Roughly speaking, this analysis presented here combine the conceptual and empirical analysis. We use conceptual analysis to dissect the idea of industrial policy and put it in a broader context of state defense. We 
support out arguments using two case studies which is part of our empirical analysis. We select two cases, China and South Korea, to substantiate our argument about how industrial policies have been incorporated into broader framework of national security strategy.

Despite our reliance on secondary data sources, we also use primary data in the form of government reports and official statistical data issued by government agencies. These primary data are important as valid information for what the governments have been doing to safeguard their economies and how they justified the uses of some neomercantilist policies to support their national security.

\section{RESULTS AND DISCUSSIONS}

\section{Industrial Policy: An Overview}

Industrial policy is one of the solid bases for making economic policies in the post-war period aimed at economic recovery and strengthening of the economic structure. Economic structuring is needed for economic transformation towards strengthening a competitive industrial sector at the global level. In this case, the contribution of an internationally competitive industrial sector is an important asset to support economic growth and wider social welfare. The fast-growing industrial sectors in many developing countries provide great opportunities for social policies to address poverty and inequality between urban and rural areas. Therefore, the industrial sector plays a strong role in generating economic prosperity. One clear example can be seen from the industrial policy in Europe being used as an engine for the post-war European economy to achieve social progress. With increasing globalization, the industrial sector has become an engine for promoting social progress (Soete, 2007).

As an instrument to encourage economic growth, industrial policies are the driving force for the domestic economy. Therefore, each country strives to make industrial policies that are integrated and have a positive contribution in the long run. Various forms or models of industrial policies are widely applied in several countries, from 
strengthening state intervention to industrial policies that refer to market liberalization.

Industrial policy is inseparable from policy networks that refer to the state's penetration mechanism into society. These networks facilitate communication between government and industry, mobilize support from community groups, and function to implement government policies. Policy networks can take the form of quasi-government groups, such as industry advisory boards, policy review groups, and think tanks, or the less institutional but patterned relationships between government agencies, legislatures, political parties, banking institutions, trade associations, labor organizations and other social groups.

State power or state capacity refers to the government's ability to extract resources from society, implement policies even in the face of social opposition, and the influence of social groups. In developed industrial countries like Japan, viewed from the country's capacity, the features of the Japanese government are very suitable in promoting industrial competitiveness and encouraging industrial cooperation. This relates to the centralization of the country, the Japanese political system characterized by a unitary government system in which the state bureaucracy is centered on the dominant political party in the country, the Liberal Democratic Party (Fong, 1999).

With regard to the role of the state in industrial policy, China is an example of a country that has succeeded in using its industrial policies to boost economic growth. Lin \& Wang (2008) see that China's industrial policy begins with economic reforms that begin with the creation of micro policies such as economic zones and assistance from non-state companies facing budget problems. This economic strategy is then followed by policies at the "macro level", namely liberalization of the price system, fiscal reform, and regulation of competitive exchange rates. 
In addition, in order to deal with the entry of foreign companies, the Chinese government made policies to encourage national companies to be more competitive than foreign companies. In this case, the Chinese government made a series of industrial policies that limit FDI in various industrial sectors which are also carried out by national business actors. Foreign investment is limited to minority ownership in the agricultural sector, the automotive industry, chemicals, machinery, paper, securities, shipbuilding, steel and the telecommunications industry. This protectionist policy trend in China was carefully planned as a longterm industrial policy. The role of the Chinese government in industrial policy, among others: First, actively manipulating the currency, Reminbi, is estimated to be undervalued between $25 \%$ and $40 \%$. Second, China implements a technical standard policy for the protection of domestic companies from foreign competition. Third, government procurement policies are used to help develop Chinese-owned technology and can provide a market for Chinese national companies. Four, the Chinese government initiated industrial policies that increasingly limit FDI in various industries that are also run by national companies (Hemphill, 2013).

Picture of industrial policy in China confirms a major form of government intervention. In this case, the intervention is aimed at providing a conducive environment for domestic companies. Restrictions on FDI are aimed at making domestic companies more competitive in sectors that are strategic sectors for the government. Regulations on industrial sectors that are opened to FDI can be seen as a form of government caution in liberalizing the industrial sector.

Meanwhile in South Korea, state intervention was carried out during the industrialization period. Machinery imports are strictly controlled to promote the domestic machinery industry. Credit is not usually extended to importers of machines that are already available in the country and, on the other hand, subsidized credit, which often reaches $90 \%$ of the value of the product, is extended to domestic buyers of machines. The Korean state prescription for private companies was to 
encourage companies to invest in heavy and chemical industries in the 1970 s and a ban on investment in consumer goods industries. Stateowned banks were also ordered not to make consumer loans. Even tighter controls are placed on the consumption sector, which involves spending foreign currency. The predominance of industrial policy with a view to 'industrial upgrading' has been a hallmark of government intervention. Korea has selected several industries as 'priority' sectors and is providing great support to them. Most of Korea's major industries were designated as priority sectors at some stage and developed through a combination of massive support and great control from the state. 'Designated' industries have priority in obtaining credit and foreign exchange, state investment funds, preferential tax treatment and other supportive measures (Chang, 1993).

The dominant government policy is directed at increasing the competitiveness of Korean industries. In this case, the government implements several restrictions and selects strategic sectors as one of the main elements of industrial development. The form of assistance to the industrial sector is also more focused on priority sectors that have received facilitation from the government. The banking regulations set by the government are also a driving force for the development of the domestic industry.

Korea's experience in industrial policy provides important lessons for developing countries. 1) Competent economic policymakers in Korea choose industrial policies that are more prudent and have long-term impacts on domestic industrial development; 2) Build institutions for recruiting broad-minded elites as economic policymakers will be required to implement industrial policies that are appropriate to developing countries; 3) Depending on the fiscal situation, developing countries may provide export and customs insurance schemes, which are considered non-prohibited subsidies to promote export-related industries; and 4) Infrastructure provisions, as well as tax and financial benefits can also be considered to promote strategic industries (Mah, 2007). 
Related to government intervention in industrial policy, Rodrik (2009) argues that there are two models of industrial policy that must be combined, namely: the traditional model in which the government takes certain sectors and provides incentives through various policy instruments (tax credits, subsidies, directed credit) and various sectoral priorities; and new model that focuses on building an institutional framework to address some of the key issues stemming from the implementation of existing industrial policies.

Economic policies that can be used to support national industry can be carried out through government intervention and incentives for the private sector. Government intervention is aimed at building industrial capital to ensure a solid manufacturing base. It is done through high levels of capital accumulation, interest rate controls and selective loan approval policies for investment in capital equipment, and high levels of investment in targeted manufacturing areas. Government policies to facilitate industrial upgrading and diversification should be used in industries with a latent comparative advantage so that once new industries are established they become competitive domestically and internationally. There are two types of government intervention. First, is policy that facilitates structural change by addressing information and coordination problems for industrial improvement and diversification. Such interventions aim to inform and coordinate improvements in the "hard" and "soft" infrastructure necessary for the private sector to grow in line with dynamic changes in economic comparative advantage. Second, are policies aimed at protecting selected companies and industries either in new, too developed sectors or in old sectors that have lost their comparative advantage (Lin \& Monga, 2010).

In addition, selectivity and targeting is required in industrial policy, as was done in the European Union in the 2000s. They use policies that focus on Research \& Development (R \& D), innovation, SMEs and so on. In addition, government officials make investment decisions that sometimes go against the market, sometimes even using state-owned 
companies as vehicles, just to build a successful industrial sector (Uvalic, 2014).

From the above description, it can be seen that government intervention in industrial policy can be carried out in several forms ranging from policies for selecting priority sectors, providing facilitation to the domestic industry, limiting FDI, banking regulations to policies to address the dynamics of problems in industrial policy development. This form of policy aims to provide protection and facilitation for the domestic industry. In the end, this policy is expected to be able to encourage economic growth, help solve social problems and develop a more competitive national industry.

\section{Industrial Policy as a Concept of State Defense}

Several forms of industrial policies implemented in several countries, such as China and Korea, illustrate how government intervention is aimed at increasing the competitiveness of national industries that are more competitive both at the national and global levels. The strengthening of national industry will ultimately contribute to the creation of social welfare. Strengthening the national industry can be seen as a form of state defense. One of the values contained in defending the country is the value of "Cinta Tanah Air" with one of the indicators "Contributing to the Advancement of the Nation and State" (Widodo, 2011).

This article sees that the awareness of individual policy makers of the need to make policies that are oriented to the interests of the nation and state which are manifested in the form of industrial policies that are prudent and oriented towards people's welfare is a form of state defense. Since the main objective of industrial policy is to promote an independent and competitive national industry in addition to protecting the national economy from the threat of unfair competition from big international business players, industrial policy can be seen as a form of state defense carried out by policy makers. 
Industrial Revolution 4 is an era of industrial transformation that is currently happening including industrial production such as robots and the industrial internet of things, augmented reality, and others. Industry 4.0 has and will continue to change many things through its connectivity and digitization in increasing the efficiency of the manufacturing chain and product quality. So, what are the threats to Indonesia? This Industrial Revolution will eliminate a lot of jobs in the world, and of course, including in Indonesia. Thus, a strategy for increasing the competitiveness of national industries and creating jobs is an important form of state defense application played by policy makers.

Why can industrial policy be seen as a form of state defense? First, industrial policies are formulated by individuals. These individual decision makers are essentially citizens, but of course with a special mandate to make policies for the benefit of the nation and state. Because of their citizenship status, the obligation to defend the state is also attached to them. Second, threats are not only military in nature. Even after the cold war, non-military threats, especially economic, outweighed military threats. The increasingly intense economic competition in international business sometimes forces countries (even developed countries) to make protective industrial policies to protect their producers to the detriment of many other countries. In this condition, a policy that protects the state and nation from the effects of unfair competition is the responsibility of defending the state from policy makers.

Third, industrial policy is essentially aimed at strengthening domestic industry and advancing the national economy. As declared by the Indonesian government in the Vision and Long-Term Development Directions for 2005-2025, the vision for economic development is:

"The realization of an economy that is advanced, independent, and capable of significantly expanding the improvement of people's welfare based on economic principles that uphold healthy competition and 
justice, and taking an active role in the global and regional economy by relying on the nation's ability and potential." (Bappenas, 2005)

Thus, industrial policies that are oriented towards achieving the above vision are very important and therefore can be seen as a form of state defense for whoever makes these policies.

Through industrial policies based on national interests, the government also facilitates increasing the competitiveness of national industries at the global level. Salsabiela (2017) explains that the government must be able to play an optimal role in helping the national industry to increase competitiveness at the global level. Several supporting policies need to be made by the government to encourage the strengthening of the national industry, one of which is policies related to strengthening human resources in local industries.

Regarding optimal role, the form of government "intervention" to increase the competitiveness of the national industry is needed. In this case, the entry of FDI into the industrial sector needs to be restructured. This arrangement talks about the presence of integrated cross-sectoral policies to emphasize the need for FDI contributions to local industrial development. The mapping of priority industrial sectors that has been carried out by the government must be followed by a series of policies that are implemented and integrated. As has been done by China and South Korea, the government provides a series of incentives and facilities to encourage priority sectors to be more competitive at the global level. This policy will be implemented properly through coordination mechanisms and information that are integrated with one another.

\section{Industrial Policy in Indonesia}

The history of the significant development of Indonesian industry began in 1983. 1983-1998 was known as the period of the birth of Indonesia's industrialization policy. This is because, at the end of 1983 , the production value of the manufacturing industry increased rapidly due to the government's tight supervision of imports, particularly 
imports of machinery. The growth in production value reached $13 \%$ on average per year during the 1970s, becoming one of the fastest in the world after South Korea and Singapore (Prawiro, 1998). But then, in 1998, coinciding with the end of the IV five-year development program, the Indonesian economy was hit by the 1998 financial crisis, so a new development policy was needed.

After the 1998 financial crisis, Indonesia's industrial growth, especially non-oil and gas industry, experienced quite intense diversification. The number of industrial companies from textiles and textile products, food and beverage, publishing and printing, rubber, rubber and plastic products, reproduction of recording media and communication equipment, and their equipment has experienced rapid growth (Rochadi, 2014). The government began to pay more attention to small industries because they proved to be more resilient to the economic crisis. Tijaja and Faisal (2014) also emphasize that after the crisis, the pro-labor society, especially workers, began to demand clarity in the recruitment process and wage standards. This resulted in the emergence of a policy of increasing wages but not in line with the growth in company productivity. Thus, protectionism is an alternative in protecting national industries to protect growing industries, such as the automotive sector and transportation equipment, machinery \& equipment. On the other hand, governments that are bound by an agreement with the International Monetary Fund (IMF) are also required to issue liberal industrial policies (Rochadi, 2014).

Post crisis to date, industrial revitalization has become the focus of the government in improving the country's economic structure. To actualize export-oriented industries, revitalization is focused on industries that employ a lot of labor (labor intensive) and those that have export capabilities. As a result, it was noted that the role of the industrial sector in the national economy increased, from $23.8 \%$ in 2000 to $24.6 \%$ in 2004 (Tijaja, 2014). Labor-intensive industries provide the largest share of output, which is around $60 \%$ due to the large population of business units. 
Furthermore, in 2004, the government launched the National LongTerm Development Plan (RPJPN) with a period of twenty years, namely 2005-2025. In Law Number 17 of 2007 concerning RPJPN 2005-2025, it is stated that the industrial sector is the basis of the strength of a strong economic structure. Thus, the development of the industrial sector is focused on eliminating monopolistic practices and various market distortions. In terms of business scale, Small and Medium Industries (IKM) are built into the foundation of the national industry, by integrating it into a value added supply chain with large-scale industries. In terms of products, product diversification is designed from upstream to downstream so that it is expected to form healthy and strong industrial clusters (Nurfadilah, 2018).

If we look back at the history of the development of industrial policy in Indonesia, one of the goals of national industrial policy that always appears is import substitution industrialization (ISI). The government always targets increasing domestic industrial products, one way is by opening investment taps in the industrial sector. This is done so that local industries can produce raw materials, auxiliary materials, and finished materials, which in other words dominate the upstream to downstream industries. Based on data from the Ministry of Industry, since 2014, the trend of import substitution industry investment has continued to increase. In fact, it is projected to reach 379 trillion rupiah in 2018-2019 (Hastuti, 2018).

In implementing industrial policies, the government must determine which industries have a comparative advantage. The assessment of comparative advantage is carried out by looking at aspects of cost analysis, long-term impact and technology (Syamsudin \& Setyawan, 2008). This study finds that the government has implemented this policy, seen from the synchronization of the Ministry of Industry's Strategic Plan with the 2015-2019 Investment Coordinating Board's Strategic Plan. The BKPM Strategic Plan focuses on investment in priority industrial sectors, namely: 1) electricity in order to support energy security, 2) labor-intensive industries, 3) agricultural industries 
to support food security and the processing industry for agricultural products to increase added value for exports, 4) maritime industry, 5) import substitution industry for domestic raw materials and consumption, 6) mining product processing industry to provide added export value, and 7) tourism industry.

The balance between national industrial development and the country's openness to investment seems ideal for Indonesia. But in fact, until now, dependence on imported raw materials has not been resolved. This was put forward as one of the main problems in the development of the upstream national industry sector because it still had to depend on imported goods (Setjen DPR RI, 2015). However, these raw material producing countries often limit sales because the economic value of importing raw materials is much lower than that of finished goods. It seems that the orientation of the import substitution industry without the establishment and resilience of the supporting sectors, for example the agriculture, livestock and marine sectors, which is sufficient, has implications for high imports in the upstream manufacturing industry.

Another problem is that the orientation of the import substitution industry which has the foundation of the majority of labor-intensive industries has implications for the difficulty of creating added value from upstream industrial products. The instability of the rupiah exchange rate often has a negative impact on labor-intensive industries, such as rampant layoffs which contribute to increased unemployment (Syamsudin \& Setyawan, 2008) and the industry's tendency to reduce working hours and reduce production.

Entering the industrial era 4.0, every country is faced with the challenge of creating industrial policy strategies that encourage comprehensive and sustainable industrial development. The development of digital technology is the main basis for the need for adjustments to existing industrial policies. Strategic steps were carried out by the Ministry of Industry, including making policies to realize the big aspirations of Making Indonesia 4.0, as an integrated roadmap to implement a number of strategies in entering the Industry 4.0 era. According to the 
Ministry, there are also quite a lot of demands for new types of work, such as digital data managers and analysts, as well as professions that can operate robotic technology for industrial production processes (Ministry of Industry, 2018). It is hoped that the increase in digitalbased industries will increase the competitiveness of national industries at the global level. Thus, when industrial policies are able to increase industrial competitiveness that can adjust to the dynamics of technological development, the government's efforts to advance the national industry can be carried out.

In order to face the industry 4.0, the government has prepared five priority industrial sectors, which include the food and beverage industry, the automotive industry, the electronics industry, the chemical industry and the textile and textile products industry. Some of the strategies that have been prepared by the government in responding to industry 4.0 include the government optimizing the existing supply chain, building digital-based infrastructure and increasing human competitiveness in the industrial sector, especially in the digital and entrepreneurial fields. Besides, the fulfillment of electrical energy needs is also closely related to national priorities in Making Indonesia 4.o. In addition, the government is also implementing an innovation policy through incentives in the industrial sector and its regulations (Nurfadilah, 2018).

\section{CONCLUSIONS}

Industrial policy in the conception of state defense is controversial. This is because industrial policies (like policies in general) are the product of collective decisions of stakeholders. Even so, because decisions are made by individuals who are also citizens, this policy can be seen as a form of how strong the commitment of policy makers to state defense.

Although the form of industrial policy represents the commitment of policy makers to the conception of state defense, we need to be careful in linking the successes and failures of this policy with the commitment to defend the state from these industrial policy makers. This is because 
policy design requires careful calculations based on cost and benefit considerations. However, in policy analysis, we can measure the desirability of a policy by seeing how much the welfare effect is produced by this policy. Based on the utilitarianism argument, we can measure the success or failure of this policy from how much the level of welfare it gets and how many Indonesians benefit from this policy.

Reflecting on the experience of industrial policy in Indonesia, it can be seen that the commitment to defend the country by policy makers is still weak. The resulting industrial policies have still failed in encouraging the rise of the national industry. For example, local industry players are still dealing with financing problems for industrial development. In addition, the use of domestic industrial products is still minimal. On the other hand, the flow of imported products also makes local industries even more dying.

We are aware that making a great industrial policy is not effortless, especially in an increasingly interdependent economic condition with increasingly stringent trade regime regulations. In conditions where the free trade regime is so strong, industrial policies in the form of subsidies and incentives for national industry will be seen as an indication of Indonesia's weakening commitment to trade liberalization. However, as economist Dani Rodrik emphasized, industrial policy is needed to minimize the negative impact of market failures. Even though this policy is populist economically, it is needed to prevent political populism which is far more risky (Rodrik, 2009). Apart from that, several policies on non-tariff barriers, especially by developed countries, show that the loopholes of free trade regulations can still be utilized. 


\section{REFERENCES}

Bappenas. (2005). Visi dan Arah Pembangunan Jangka Panjang (PJP) Tahun 2005 - 2025. Retrieved from Bappenas:

https://www.bappenas.go.id/files/1814/2057/o437/RPJP_200 5-2025.pdf

Chang, H.-J. (1993). The political economy of industrial policy in

Korea. Cambridge Journal of Economics, 17, 131-157.

Creswell, J. W. (2014). Research Design: Qualitative, Quantitative and Mixed Methods. Thousand Oaks, CA: Sage Publications.

Fong, G. R. (1999). State Strength, Industry Structure, and Industrial

Policy: American and Japanese Experiences in Microelectronics.

Comparative Politics, 22(3), 273-299.

Hastuti, R. K. (2018, Juni 20). Investasi Industri Substitusi Impor Rp 379 T. Retrieved from Investor Daily Indonesia:

https://investor.id/archive/investasi-industri-substitusi-imporrp-379-t

Hemphill, T. A. (2013). China's National Champions: The Evolution of a National Industrial Policy - Or a New Era of Economic.

Thunderbird International Business Review, 55(2), 193-212.

Lin, J. V. (2008). China's integration with the world: Development as a process of learning and industrial upgrading. Policy Research Working Paper 4799. World Bank, Development Economics Vice Presidency \& World Bank Institute, Finance \& Private Sector Development Division, Washington, DC.

Lin, J. Y., \& Monga, C. (2010). Growth Identification and Facilitation:

The Role of the State in the Dynamics of Structural Change. .

Policy Research Working Paper 5313. The World Bank

Development Economics Office of the Vice President.

Mah, J. S. (2007). Industrial Policy and Economic Development:

Korea's Experience. Journal of Economic Issues, 41(1), 77-92.

Ministry of Industry. (2018, Maret 20). Making Indonesia 4.O:

Strategi RI Masuki Revolusi Industri Ke-4 (Press Release).

Retrieved from Ministry of Industry:

https://kemenperin.go.id/artikel/18967/Making-Indonesia-

4.0:-Strategi-RI-Masuki-Revolusi-Industri-Ke-4

Nurfadilah, P. S. (2018, Juli 24). Menuju Industri 4.o, Ini 5 Sektor

Industri Prioritas Menperin. Retrieved from Kompas:

https://ekonomi.kompas.com/read/2018/07/24/132835726/m enuju-industri-40-ini-5-sektor-industri-prioritas-menperin 
Prawiro, R. (1998). Pergulatan Indonesia Membangun Ekonomi:

Pragmatisme dalam Aksi (Penyunting: Frans M. Parera).

Jakarta: PT. Elex Media Komputindo.

Rochadi, S. (2014). Kebijakan industrial(isasi) dan kontinyuitas konflik industrial pasca krisis ekonomi 1997/1998. Masyarakat, Kebudayaan dan Politik, 27(2), 91-103.

Rodrik, D. (2009). Industrial Policy: Don't Ask Why, Ask How. Middle East Development Journal, 1(1), 1-29.

Salsabiela, B. F. (2017). Upaya Bela Negara Untuk Menggerakkan Industri Kecil Nasional Dalam Lanskap Global Kontemporer. Jurnal Pertahanan \& Bela Negara, 7(3).

Setjen DPR RI. (2015). Analisis Ringkas Cepat: Kebijakan

Pengembangan Industri Manufaktur Nasional. Biro Analisa Anggaran dan Pelaksanaan APBN. Retrieved from Dewan Perwakilan Rakyat Republik Indonesia: http://berkas.dpr.go.id/setjen/dokumen/ puskajianggaranAnalisis-Ringkas-Cepat-Kebijakan-Pengembangan-IndustriManufaktur-Nasional-1448259790.pdf

Soete, L. (2007). From Industrial to Innovation Policy. J Ind Compet, 7, 273-284.

Syamsudin, \& Setyawan, A. A. (2008). Foreign Direct Investment (FDI), Kebijakan Industri, dan Masalah Pengangguran: Studi Empirik di Indonesia. Jurnal Ekonomi Pembangunan, 9(1), 107-119.

Tijaja, J. \&. (2014). Industrial Policy in Indonesia: A Global Value Chain Perspective. ADB Economics Working Paper Series No. 411. Phillipines.

Uvalic, M. (2014). Industrial Policy in Europe. Paris Brief. Widodo, S. (2011). Implementasi Bela Negara Untuk Mewujudkan Nasionalisme. Jurnal Ilmiah Civis, 1(1). 